\title{
Reading Silenced Narratives: \\ A Curricular Journey Into Innu Poetry and Reconciliation
}

\author{
Julie Vaudrin-Charette
}

University of Ottawa

\begin{abstract}
Using a life writing research methodology in this article, I seek to understand the complexities implicated in reading silenced narratives as a way towards reconciling internations relationships. To do so, I weave in the poetical territories of Josephine Bacon, Innu poet from Pessiamit, Quebec. I analyse how a poetic text has created spaces for reinterpreting silence[s], that journey into and beyond my whispered narratives as an emerging, settler scholar and curriculum theorist. As I tune into several layers of silences, I examine the pedagogical implications lying within public and intimate territories of silenced narratives and the narrative(s) of silence(s) in our various practices as educators.
\end{abstract}

Keywords: Postcolonialism; Indigenous education; educator's role; pedagogy

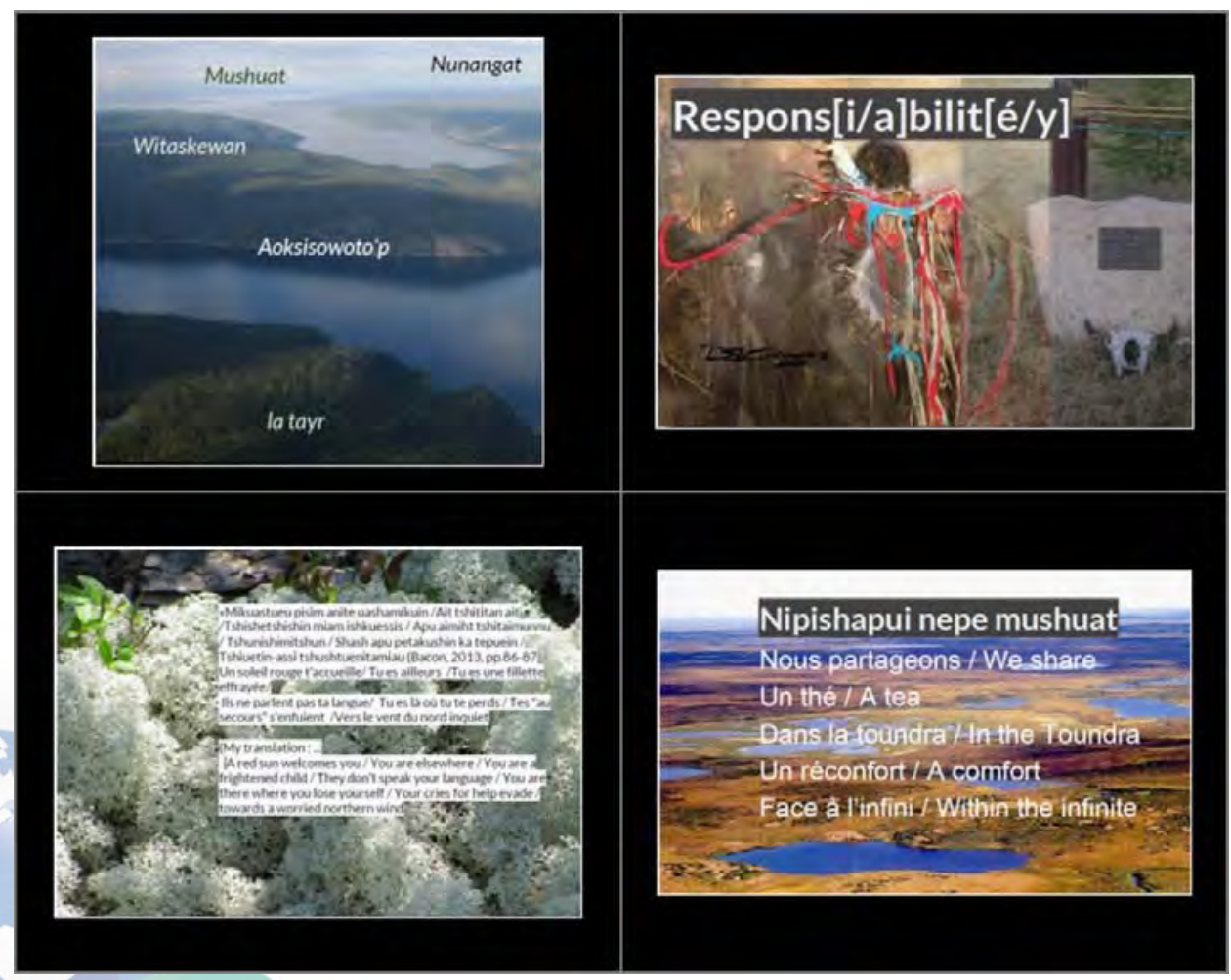

Figure 1. A visual abstract is offered here as an alternative way to enter the space of silenced narratives of symbolic literacies (see Battiste, 1986). 


\section{Reading Silenced Narratives: A Curricular Journey Into Innu Poetry and Reconciliation}

In this article, I enter a conversation on the various ways we might teach and learn silenced narratives. To do so, we might first ask, who defines "silenced" narratives? How can our teaching practices recognize the various ways in which we are attentive-or not - to various voices that are outside of our contexts of recognition? How should we approach silenced narratives in class? How might we work within, and revisit representations of "indigenous" and "land" in the context of Quebec, where I am from? In response to such crucial curricular questions, I draw on four pedagogical moments that create what I am calling a lived poetic artefact. In this essay, then, I aim to illustrate my poetic journey as an educator and as a lifelong learner. Each of these moments reflects the ways I relate to silenced narratives within my teaching and learning as a nonIndigenous curriculum theorist, mother, and educator now living on the traditional, unceded territories of the Algonquin Anishinaabe people.

\section{Silenced Narratives?}

An initial word of caution might be appropriate. Should I refer to a well-respected Innu author in Quebec as "silenced"? After all, Joséphine Bacon was shortlisted for the 2014 Governor's General Literary Awards (Note: the award went to American-Canadian Cherokee author Thomas King). Moreover, in June 2015, she became the first Innu author to enter l'Institut de France, invited by Haïtian-Québecois author Dany Laferrière for his induction ceremony. Natasha Kanapé Fontaine noted the irony of the situation in Le Devoir: "Two Quebec poets enter the famous Académie française-one through the main door, the other, a tiny woman carrying the fabulous heritage of our language, Innuaïmun, on her back" (2015, par. 6, translation). As one can see, the term "silenced narratives" is, indeed, charged with several layers of colonization. In line with Hoy (2001), I recognize the risk of creating racial binaries in tuning into silenced narratives. In fact, my own positionality, as a francophone Québécoise scholar attending a bilingual university, writing this story in English, can easily become tangled in such argumentation. Rather, my intention is to translate Bacon's poetry without betrayal or appropriation. Hence, the translation effort should be seen as tiny threads, containing possibilities to expand, anchored in open-spaces inspirited by brief encounters with the author. To illustrate these invisible threads in humility and respect, I refer to them as whispers. My hope is that whispers, and the type of intimacy they create, can be reflective of a certain way of listening, which, in turns, reveals itself as a certain way of learning.

\section{Echos of Silence}

Buber (2003) refers to silence as a mediating moment, where "nothing needs to mediate between me and one of my companions in the companionship of creation, whenever we come near one another, because we are bound up in relation to the same centre” (p. 25). In this iteration of silence, genuine relationality stems from stillness and attentiveness. A certain connection to the land and to each other may occur.

To begin, I point out some of the various complexities encountered in developing a relational, place-based ethics. In so doing, I employ the concept of Aokisisowaato'p, a 
Blackfoot concept that calls our attention to "the ethical importance of visiting a place as an act of ethical renewal that is life-giving and life-sustaining, both to the place and to ourselves” (Blood, Chambers, Donald, Hasebe-Ludt, \& Big Head, 2012, p. 48). To understand such attendance to place, in this essay, I translate and analyze poetic lines from Bacon (2013) “Nipishapui nete mushuat - Un thé dans la toundra," as aesthetic, intertextual objects in my attempt to find ways to teach and learn from silenced narratives. Secondly, I enter the emotional affect of silenced narratives. Here, a poem inspired by silence is contextualized within the historical, linguistic, and physical suffering experienced by Indigenous populations at the hands of the Indian Residential Schooling system (IRS), and through the intergenerational consequences of this regime. Drawing on tensions between absences and presences in the Canadian curricular landscape, I focus on language as a central component of a reparative curriculum (Mishra Tarc, 2011). I note absences and losses concerning Indigenous languages in Canada, and the sense of respect and resilience derived from this tensioned, pedagogical space. Third, I explore silence as international, intercultural, and pedagogical spaces of such silences. Finally, I enter the narratives of silence in pedagogy. How can they inform our process of reading silenced narratives? How may we as teachers position "silenced narratives" in reparative curriculum, particularly in how we relate to each other as nations, as humans, as learners, and as praxis of indigenizing the curriculum (Battiste, Kovach, \& Balzer, 2010; Chambers, 1999) and reconciling inter-nation relations? Inspired by Andreotti, Stein, Ahenakew, and Hunt (2015), I end with a reinterpretation of silenced narratives when revisiting our colonized relationships to land and languages as part of a reparative curriculum.

\section{Towards Poethical Readings of Indigenous Narratives}

As a settler college educator, I am interested in pedagogical crossroads derived from inter-cultural and inter-nations collaborations. In my first steps of my doctoral research, I examined emerging pedagogical collaborations between Quebec colleges and First Nations, Metis, and Inuit communities. In this context, considering my reading of silenced narratives assisted in engaging a curricular conversation on absences. On a global scene, I join other voices in seeking to de-monoculturalize curriculum (Abdi, 2011), and bringing forward ethical considerations into the discourse of international education and inter-nations education. (Emongo \& White, 2014; Garson, 2013; HaigBrown, 2008; Kulnieks, Roronhiakewen Longboat, \& Young, 2010; Pidgeon, 2008; Pinar, 2006a; Pretceille, 2013; Wang, 2004). How does the coexistence of epistemologies influence our reading of silenced narratives?

To understand and build linguistic richness into curriculum, Chambers (1999) invites curriculum theorists to listen to "the languages and dialects that both predate and follow the arrival of English and French” (p. 143). This brings an opportunity to see other aspects brought by socio-cultural readings of text, notably the relations of power reflected in the absence-presence relationships (Hall, 1997). A curriculum on reconciliation needs to include dialogue on how history and identity shape our learning processes (Stanley, 1999; Tuck \& Gaztambide-Fernández, 2013). In response, I wish to find ethical-relational ways to read and be influenced by Bacon's poetry. Through reading Innu poetry, I began a journey within, which has transformed my reading of literatures-of-the-other, my approach to teaching, and my reading of my practice and agency as an educator. 


\section{Knitting Personal Narratives}

Poetry and other ways of telling stories in education can help us to "better understand the intricacies of language. . .by creating opportunities for learner[s]. . to foster an excitement about developing aesthetically pleasing forms of expressions” (Kulnieks et al., 2012, p. 94). Moreover, Leggo (2008) proposes life writing research as an "ongoing process of understanding how we invest space and chronology with significance” (p. 20), and invites us to carefully construct our stories. Poetry does not emerge when weaving our learning, readings, teachings, writings, and listening — without the silences.

In life writing research, transformative engagement emerges from new ways of seeing and understanding different worlds (McIvor, 2010, p. 137). Archibald (2008) invites readers to web the invisible and visible connections among several stories as a way to engage one's mind, heart, body and spirit. Weaving personal stories offers narrative foundations to our intentions as a curriculum developers and theorists (Blood et al., 2012; Pinar, 1974; Weenie, 2008). A poetic knitting of personal narratives, or currere (Pinar, 1974), opened spaces where I could reflect on specific moments of (my) educational path and their transformative or limiting powers. It emerged as a way to tell this story.

I grew up on the North Shore of Quebec, on unceded Innu territory. It was there that I met Josephine Bacon, originally from the Pessiamit. My experience of hearing her poetry was transformational for several reasons that I will recall in this paper. The first reason was based on assumptions about territory. As a child, I spent my summers on the beach, close to Pessiamit. In the winter, the beach covered with ice; the water transformed to mini-iceberg islands, becoming imaginary boats, letting go of the land from which we came. I did not realize this connection until my family moved. While in "exile,” I started longing for the land, and realized that the land inhabited me.

Bacon and I might have looked at the similar landscapes in our childhood, over different times, and thus both of our experiences of longing for the land entail proximity and distance. My migration was voluntary, however, and included my family as a whole. Hers was forced by the Canadian Residential School System. How does our relationship to migration influence emotions like fear, trust, protection, and care? What does it mean to survive? What does it mean for me? Landscapes, land-escapes, or land-spaces?

Several of the elements described above-nomadism, language, place, encounters, and absences - are themes that have been central to my life-path, and still haunt and inhabit me as an emerging curriculum theorist. As such, I identify with Chambers (2006) remarks:

In fiction written by Aboriginal people three motifs strike the reader: the land-loved, lost and found; creation and re-creation as simultaneous events where life, time and space are one force in perpetual motion; and finally, homecoming. Oh yes, and there is a fourth: [...] multiplicities that constantly erupt into chaos, a chaos we must not fear but through which our stories are always map and compass. (para. 45) 
Attempting to recognize and navigate such chaos has profound echoes with Andreotti, Ahenakew, and Cooper's (2015) in their mapping of the complexities and paradoxes that emerge in different processes and ideals of decolonization (p.22), which I hope to further explore in future research.

For now, we may ask: How can we read poetic Innu esthetics in ethical ways as a way to bring a conversation on processes of indigenization and reconciliation in Quebec's college curriculum? As an initial echo to Andreotti et al. (2015), I examine how we may, as educators, follow various pedagogical paths in reconsidering a curriculum of reconciliation (and beyond), as an attempt to focus "on equipping people to face the incoherence (and frustration) of the juxtaposed, incommensurable contexts they will have to inhabit, navigate and negotiate in” (p. 30).

Here, a multilingual poetic evocation of the countenance of [silence] becomes an in-between space.

Whispers.

Landscapes.

Mushuat.

Toundra.

Land-escapes.

Eka tshituk.

Chut!

Quiet! Quoi?

Land-espaces.

Echo.

We?

Nipishuat nepe Mushuat.

Tshinashkumitin.

\section{Whisper. "Landscapes.”}

As we journey on the land, or dwell, or are exiled, our relationship to place opens conversational spaces about how we relate to each other as a moment of ethical renewal. These concepts of sustenance and of sustainability, and their cultural evocations of reciprocity, have inspired my journeys into the territories of curriculum inquiry.

My first reading of Bacon's poetry is an analysis of her (possible) relationship to land through entering these words: 


\section{An Excerpt From Un thé Dans la Toundra - Nipishapui nete Mushuat, a Poem by Joséphine Bacon (2013)}

Tshitamishkun e minuat assi

Anite etain

Missinaku niminiku

Papakassiku nuitsheku

Uapitsheushkamiku nitashamiku

Massekushkamiku kashinamu nissishikua miaian

Ninatuapamau mishta-utshekataku

Uin nuitamak tshe ituteian

Ekute ute namian ashit uashtuashkuan

Nipimishin, apu matenitaman

Ninipun
Tu me promets une terre pure

Où tu existes

Missinaku m'abreuve

Papakassiku court avec moi

Le lichen me nourrit

La mousse soigne mes larmes

Je reviens à la grande étoile

Mon guide

C'est ici que je danse

Avec les aurores boréales

Étendue, Je n'agonise pas

In the purity of promised land

Where you exist

Missinaku* quenches thirst

Papakassiku** runs with me

Lichen nourishes me

Moss sponges my tears

I come back to the great star

My guide

Here I dance

With Aurora borealis

Lying

Not agonizing.

(pp. 16-17, English interpretation

by author of article)

* Missikanu (Master of Waters)

** Papakassiku (The Master of

Cariboo)

\section{Whisper. "Mushuat."}

In this first hearing/reading of the poem, several elements can be interpreted as symbols of the author's relationship to the land. Lichen, aurora borealis, moss, and the references to Papakassiku and Missikanu bring us into the tundra. The poet can also become absorbed in interpretations, and become a symbol of "Indigenous," "Peoples," or "Native voice." I interpret Bacon's authorship as "speaking for," or "as a member of one’s own group" (Werner, 2000). Werner (2000) suggests that, "speaking... from one's location has a form of authority based upon the assumed richness of first-hand experience” (p. 203) A last word of caution comes from Hoy (2001), pointing out some of the risks of the endeavor of pedagogical representation of Native women narratives: 
the risk of creating Indigenous/non-Indigenous writer binaries, of using race as explanatory, and of using these texts as cultural documentation (p. 20). What are the hidden stories behind this initial representation of an author's relationship to her land of origins?

\section{Whisper. “Toundra.”}

A first representation of silenced narrative in relationship to territory could remain a mere contradiction between the desire for indigeneity and the negation of the past traumatic events. In labeling the author as "Indigenous," critics point out that the author is perceived as a cultural representative, as speaking for Indigenous people in Quebec. In fact, through Bacon's celebrated Indigenous poetry, Quebec's literary critics bring to light intercultural tensions in Quebec:

After oppressing their people, we now see Joséphine Bacon as a key figure in Aboriginal culture. Where does she stand in the mist of this popularity? Does she think we are trying to embrace a new "us," when we were throwing rocks at Mohawks during the Oka crisis? (Leclerc, 2014, p. 24) ${\text { (translation })^{1}}^{1}$

Leclerc points out the paradox between celebrating a poet's Indigeneity and the layers of colonization that took (take) place in Quebec and elsewhere in Canada. Ralston Saul (2015) observes that there is need to go beyond postures of empathy, romanticism, or denial of land claims to tackle reconciliation: The creation of new narratives is needed.

In this reading, idealizing Bacon's relationship to land, I am blinded by my own desire to forget harmful events of the past and find a way to relate. I am prisoner of racial binaries. Could envisioning Bacon's relationship to land through poetics; aesthetics, or cultural lenses be solely a “premature attempt at reconciliation” (Tuck and Yang , 2012). These authors warn:

The absorption of decolonization by settler social justice frameworks is one way the settler, disturbed by her own settler status, tries to escape or contain the unbearable searchlight of complicity, of having harmed others just by being one's self. The desire to reconcile is just as relentless as the desire to disappear the Native; it is a desire to not have to deal with this (Indian) problem anymore. (p. 3)

In the same way, Bacon's work cannot be seen as speaking for all First Nations in Quebec; as an educator/researcher, I cannot speak for all settler descendants, or only from that point of view. I feel a tension between proximity to an Indigenous voice and the cultural distance created through genocide of language and culture. The pedagogical endeavor is to find ways to go beyond my positionality as an outsider without erasing the other.

\section{A Poethical Polyphony}

Looking for other readings of silenced narratives, I turn to Buber's (2003) suggestion: 
When we really understand a poem, all we know of the poet is what we learn of him [her] in the poem-no biographical wisdom is of value for the pure understanding of what is to be understood: the I which approaches us is the subject of this single poem. But when we read other poems by the poet in the same true way their subjects combine in all their multiplicity, completing and confirming one another, to form the one polyphony of the person's existence. (p. 17)

\section{Whisper. “Land-escapes.”}

In reading a second excerpt, I revisit Bacon's (2013) self-identification as a Tundra nomad.

Bacon (2013) writes:

Kasikat apu natamik papamutein utenat / Nin au ka matshit Mushuat
Je ne suis pas l'errante de la ville / Je suis la nomade de la Toundra.

I am not a lost soul in the city/

I am a tundra nomad. (pp. 56-57)

(English interpretation by author of article)

In this second excerpt, lichen becomes grass, using the tensions between Bacon's positionality as urban, Aboriginal artist in Montreal, and reclamation/celebration of the Tundra as cultural territory. Having those two images side-by-side, the "tundra poet" and "the resilient urban," enriches my reading of her poem. A short promotional video evokes the dynamics between the places we live and the inner territories. In this clip, she walks in her white socks on the green grass of Parc Lafontaine, a landmark in Montreal. She reads, first in Innu-aïnum, then in French, a poem that is not part of the book, but which refers to "the songs that inhabit us." She concludes with an invitation: "La ville où j'erre est l'espoir que tu m'accueilles / Puisque / Je suis toi." As envisioning tundra and city as juxtaposed in some Indigenous identities provoked me, I translated this vision into a workshop with college students, as a way to include identity conversations in my work as a pedagogical advisor in a college. Bacon's words became an entry point for students to describe and share about the land they were from, and read into the poem to imagine whom the author might be, from where the author might come, and so on.

In fact, my goal is to open spaces for paradigm shift about territory/Indigeneity/Indigenous, where an urban Aboriginal artist, living in exile and having been through IRS, can still celebrate territory and language from within. When stories are heard, performed, and contextualized, they create various openings into curriculum, including a particular sense of ethics. For my students, a conversation ensued, focusing on deconstructing stereotypes, as an initiation to exploring racialization and identity in a social science class. Part of this initial conversation with the students aimed at deconstructing representations of Aboriginal and land. The image of Joséphine Bacon as both a "tundra nomad" and a "resilient urban woman" created new readings of her poems. In this sense, can we dream of new readings on reconciliation based on our collective responsibilities? How may we incarnate Reconciliation principles (TRC, 
2015), which include 'supporting Aboriginal peoples' cultural revitalization and integrating Indigenous knowledge systems, oral histories, laws, protocols, and connections to the land into the reconciliation process” (p. 4), in our everyday practices?

\section{Reading Into the Absence of Bacon in College Curriculum}

What can reading into the absence of an Innu author in the Quebec college curriculum teach us about colonization?

Stanley (1999) asks us to "recognize that the language we speak, English (with some help of French), has displaced and silenced the languages of the people that populated the land on which our houses now sit” (p. 36). In this sense, the term silenced narratives refers to denial and unrecognized presences in history, language, land, and identities. Silences can refer to the lasting impacts of the annihilation of territorial rights of First Nations, Métis, and Inuit (Chambers, 2012), and to the loss of educational rights to language(s) (Egéa-Kuehne, 2012).

My next whisper describes pedagogical endeavors in this regards. In a context of reconciliation, Simon (2005) mentions our responsibility as educators to frame testimonies about residential schools in a pedagogical manner.

\section{Whisper. "Eka tshituk. Chut.” Silence as Violence \\ An excerpt from Bacon’s (2009) poem, Tschissinuatshitakana}

Eka tshituk.

Nikanuenimikaun.

Ninekatshikaun.

Tshiussan nin.
Silence.

Je suis adoptée.

Je suis maltraitée.

Je suis orpheline.

\section{Silence.}

I am adopted.

I am maltreated.

I am orphaned. (pp. 54-55, translation)

In this third whispered excerpt, lichen is seen in its fragility. Looking at what the verse does not say (Werner's absences) induces several other possibilities. Werner (2000) remarks, "questioning absence interrupts the taken-for-grantedness of dominant text and allows for richer readings," including ways to "protect privilege and marginalize opposition” (p. 205). In the residential school system, many Innu-aïnum speakers, along with Cree, Inuktitut, Michif, and others were ostracised and deprived of the right to learn in their first language. According to Statistics Canada's most recent census (2011), Innu/Cree is spoken by 11,335 persons in Quebec. The Canadian Residential School System, in its objective of obliterating Aboriginal culture and language, obliged stolen children to let go of the land. Testimonies of suffering are inherent to the work 
undertaken by Canada's Truth and Reconciliation Commission. However, as Simon (2012) points out, listening to testimonies, though necessary, does not guarantee a renewal of ethical relationships between Aboriginal and non-Aboriginal Canadians. The formal and aesthetic operations of works of remembrance hold infinite lessons if learners can bear to make meaning from a traumatic history's difficult content (Simon, 2005, cited in Mishra Tarc, 2011).

Stories of the survival of culture, against all odds, are less present in the main discourse. Josephine Bacon's poetry can be read as a story of resilience, maintaining a strong inner connection to her land and language despite exile and fear. Her connection to the land remains as an inner song; perhaps this is what attracted me to her words. In this context, her work may be referred to as a silenced narrative. It may also be referred to as resilience.

Bacon's poetics of resilience, published in Innu-aïnum and French, also echoed in my family. As I approached her at the book launch for a dedication, I found myself saying: "My son does not speak Innu, but I am buying your book for him." In her dedication (see Fig. 2), she included that notion of language, "ces mots dans ma langue, je te les offrent." Indeed, as I came home, I read the book with my son in both languages, playing with words and sounds unknown, and rejoicing in their introduction in our landscape.

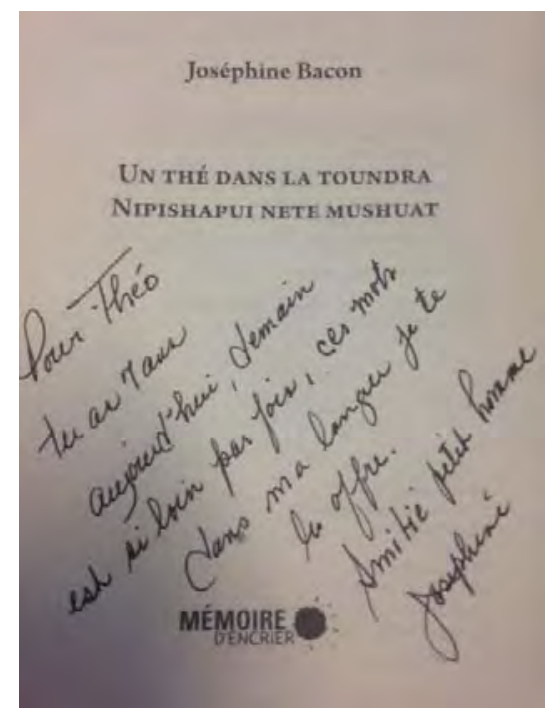

Figure 2. Joséphine Bacon’s dedication

In Canada, at least, home is that place where the past is continually present, both complicating this moment right now, and giving us and them, children and students, the courage and the confidence to face the future (Chambers, 2006). This is part of why I am engaged in this process, for current and future generations, not as a savior, but as a listener.

Entering deeper, I plunge into the emotional affect of silenced narratives. Here, a poem inspired by silence is contextualized within the historical, linguistic, and physical suffering experienced at the hands of the Indian Residential Schooling system (IRS). 


\section{Whispering. Wish. Nipishui nete Mushuat}

I come back to the texture of lichen. Soft. Taking its shape back. Growing close to the land. Growing slowly, horizontally. Opening of spaces. Land-spaces.

I tune in to absences and losses with regards to Indigenous languages in Canada, and the sense of respect and resilience derived from this tensioned pedagogical space. Taking a distance from voice and authorship of text allows for a different reading of the poem, what it says about experiences of oppression, and how it relates to a tension of distress or trauma felt. In the poem below, a child is silenced and frightened.

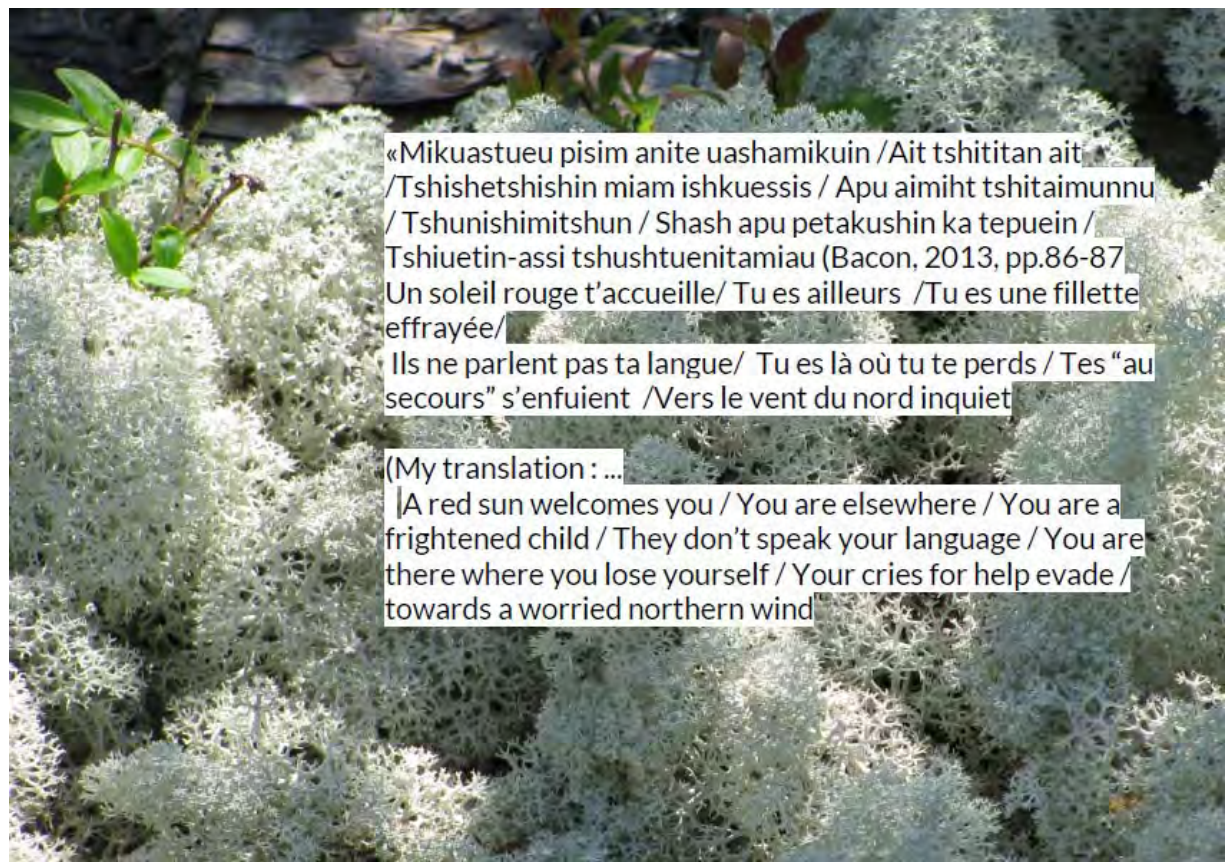

Figure 3. Poem excerpt from Bacon (2013, pp. 86-87). I have juxtaposed this image of the Tundra lichen with Bacon's poem.

As I experienced Bacon's performance of the poem, spoken in Innu-Aïnum, I was struck by a moment where her voice became frail. I cried without knowing what her words were, perhaps because, intuitively, her words echoed in my history. Intercultural linguists Uryu, Steffensen and Kramsch (2014) explore how "the increase in human migration ha[s] catapulted intercultural interaction out of modernity," so that "the words [we] speak are not necessarily [ours] and the memories these words evoke are not necessarily shared” (p. 42). Uryu et al. (2014) suggest that a micro-attention to emotional responses might uncover new information on processes operating at a subconscious level. Their account of linguistics viewed on multiple dimensions, emotional, unconscious, and energetic responses to certain stimuli, provides insights on defining what an ecological perspective means for learning and teaching languages. In their empirical method (filmed video conversations) they deconstruct various representations affecting language, as shown in this example:

Six decades of post-war trauma and cultural accusation and guilt has accumulated into a high-energetic symbol, and on the latter the full energy 
of this symbol is released in a short moment, exploding in strong emotional and cultural cascades in the entire dialogical system. (Uryu et al., 2014, p. 53)

How might this apply to our experiences of silenced narratives? May this echo in going beyond the "narcissistic isolation” evoked by Pinar (2006b) when he writes:

Our problem of proximity to the nightmare that is the present, we. . .can encounter the "other," and in so doing, reconfigure our present, thereby providing passages into the future. (para. 5)

Somehow, this invites quieting a genuine "desire to help” in order to learn to relate. This concern about ones intention is qualified by Buber (2003) as "technical dialogue” (p. 12). In silence, a paradigm shift may occur between observing and on-looking, intention and attention, restlessness and stillness.

\section{Whisper. “Quiet ! Quoi?”}

\section{A Poethical Responsibility Transcends}

The lichen is gone. Land is stolen. Children are missing. Sisters are still missing. Silenced narratives are political. Actual. I dream of resilience confronted with adversity. I also dream of collective responsibility. I dream of curriculum that does not erase, negate, or drown diversity.

Here, weaving in Buber's (2003) recognition of silence as a fundamental force of transforming our relationships, and our experience of "becoming human" with Werner's (2000) questions on voice and absence in authorship brings perspective to an educator's journey in reading silenced narratives. To repair social relations our attentiveness to an inherent brokenness within, between, and across our shifting selves is required (Mishra Tarc, 2011).

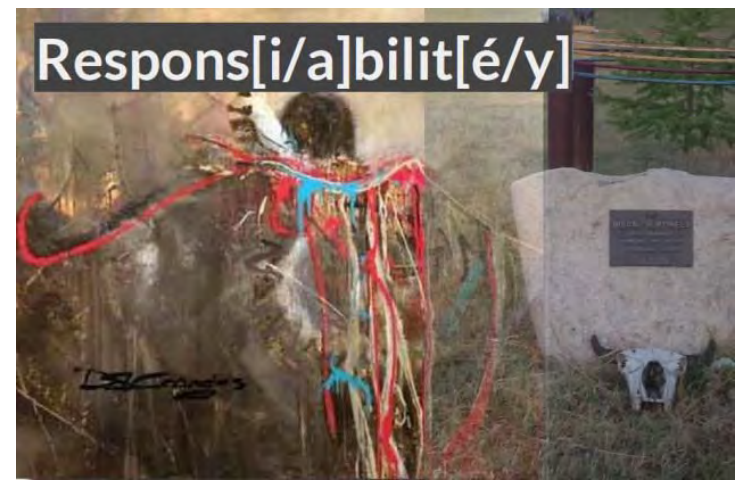

Figure 4. A painting by Diane St-Georges honoring the memory of missing women on unceded Anishnaabe territory. Juxtaposed with Bison Sentinels, monument at First Nations University.

Nous revenons ouvrir le dialogue dont nous rêvons.

Parce que rien ni personne ne peut vivre longtemps étouffé dans le silence. 
We come back for the dialogue we envision. Nothing and nobody, can live strangled in silence.

(Natasha Kanapé Fontaine, 2015, p. 5)

In the classroom, this may be compared to how we approach silence as educator? Do we find it intimidating? Helpful? Pedagogical? Perhaps, it is misinterpreted as a lack of interest and engagement on the student's part. However, it has again several layerssome of it relating to how we create spaces for our students to interact, others to how we respect silence as a fundamental space in communication. Buber (2003) describes this as letting go of "monological" (centered on self) dialogue. In my initial teaching experience, when confronted by silence, I felt uncomfortable and responded by focusing on how to escape the moment, creating a restlessness that did not serve the students. In retrospect, these particular moments taught me to suspend judgment, to listen with my eyes. "Chut!" Stand still. Wait. Such could be the teachings of silences, if we tune in.

\section{Whisper. "Echo."}

"What kind of a passport will allow us to cross the borders within this country, as well as beyond it, to be at home here, as well as, abroad?”

(Cynthia Chambers, 2006)

For Battiste (2010) developing “what Elder Albert Marshall called 'Two Eyed Seeing'” would

bring a powerful and dynamic contribution to solving issues of racism and Eurocentricism ...through normalizing Indigenous knowledge in the curriculum so that both Indigenous and conventional perspectives and knowledges will be available-not just for Aboriginal peoples, who would be enriched by that effort, but for all peoples. (p. 17)

In the following unpublished poem dedicated to Dr. Stanley Vollant, Bacon evokes a transcendence of imaginary, and real boundaries.

Ma richesse s'appelle

saumon

ma maison s'appelle

caribou

mon feu s'appelle

épinette noire

mon canot s'appelle

boulot

ma robe s'appelle 


\section{lichen}

ma coiffe s'appelle

aigle

mon chant s'appelle

tambour

moi je m'appelle

humain

my wealth is called

salmon

my house is called

caribou

my fire is called

black spruce

my canoe is called

birch

my dress is called

lichen

my headdress is called

eagle

my song is called

drum

and I am called

human

(Translated by Museum of Human Rights)

In-spirited by the words of scholars like, Ng-A-Fook (2010), one might ask:

How might we provoke an asking of narrative moments, of thinking, of doing, that takes time now to act in response to the ecological things we do, could do just now, and/or put off doing just now? (p. 53) 
Indeed, are we as educators attempting to transform our pedagogies, curriculum, and institutions according to the recommendations of the Truth and Reconciliation with regards to our collective responsibility? How may we use the current momentum towards reconciliation in Canada as an exceptional agency to understand how history, identity, languages, and land shape our learning processes?

\section{Whisper. "We"}

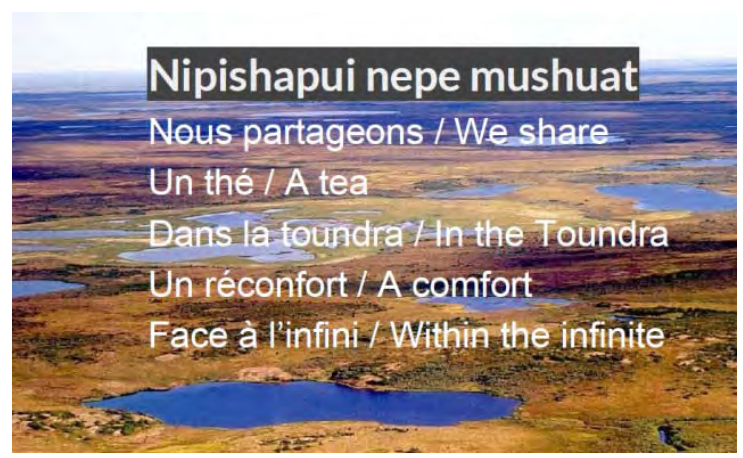

Figure 5. Poem by Josephine Bacon juxtaposed with photo of Tundra (Bacon, 2013, p. 86-87)

Wang (2004) identifies a "third space" (p. 4.) in the double encounter-alterity in the other and the other in oneself. Wang (2004) explains that in the third space one travels "beyond the current forms of life" (p. 16). The third space opens when the stranger calls one out of oneself, when the stranger inside oneself emerges, enabling one to move away from home toward a destination not yet known (Pinar, 2006b).

If we are to read silenced narratives in post-colonial ways, are we ready to accept the transformation that may occur in this liminal space? In Buber's (2003) space of genuine dialogue, the subject-object relationship is transformed by presence:

This man is not my object; I have got to do with him. Perhaps I have to accomplish something about him; but perhaps I have only to learn something, and it is only a matter of my “accepting.” (p. 12)

Reading this last verse of Bacon's book, I relate to silence as comfort and I see its pedagogical potentialities. Exploring the unsaid plays an essential role in shaping relationships, dialogue, and becoming "wide aware” as educators. Buber (2003) notes the powerful incidents of dialogue occurring when he says "in its highest moments dialogue ...is completed outside contents, even the most personal, which are or can be communicated" (p. 5).

Investigating silence as communication, he continues:

We may term this way of perception becoming aware. It by no means needs to be a man of whom I become aware. It can be an animal, a plant, a stone. No kind of appearance or event is fundamentally excluded from the series of the things through which from time to time something is said to me. Nothing can refuse to be the vessel for the Word. The limits of the possibility of dialogue are the limits of awareness. (p. 13) 
I have attempted to point out challenges, as educator and curriculum theorist in Quebec, in my capacity to inhabit or imagine spaces of liminality with Indigenous and non-Indigenous ways of knowing and doing. Certain poetic inquiries have provided a space for me to reconsider my relationships to territory and engage in a sense of proximity. Buber (2003) identifies this as letting go of "monological” (centered on self) or "technical" (centered on intentions) dialogue, to enter "genuine dialogue," characterized by open meeting spaces, and being fully present to relations/relationships.

Silence tunes in to the irrational world of intuition, ancestors, feelings, dreams. Despite the sometimes esoteric connotations given to silence as a way to hear intuition from the mainstream world of academia, the experience of intuition is part of the human experience. What happens when, as an educator, I "trust [my] organic work which preserves what is worth preserving?” (Buber, 2003, p. 11)

\section{A Tea in the Tundra}

\section{Whisper. “Nipishuat nepe Mushuat."}

At ceremonial feasts, why is it important to recognize those who have been invited? One answer is that the act of recognition has been found to be an effective way of negotiating a reality that seems to range from the utter destructiveness at one end to sublime harmony at the other.

E. Richard Atleo (Umeek), (cited in Ralston Saul, 2015, p. 248)

I have enjoyed and suffered silences as a means of creating ways to relate which encompasses all these landscapes, land-escapes, and land-espaces.

Drinking tea in the Tundra, I visualize stillness, quietness that is soothing through the presence of the other. I see Buber's (2003) "intention of establishing a living mutual relation between himself and them" (p. 39), where, despite our cultural differences, we accept and learn different ways of listening, especially when we are faced with listening to a charged colonial past. (Simon, 2012; Tuck \& Gaztambide-Fernández, 2012; Stanley, 1999). I visualize reconciliation.

I am sitting in the Tundra, with you, as your guest. I am drinking tea, thus being aware of "I"; the tea is hot, sipping slowly. The wind around us claims our silence. Our eyes claim silence. In this moment, "puisque je suis toi", we are. You are teaching me to stand still. To respect the land. To respect my relations. To respect the past. And re-learn how we can be. Your whisper, «tundra as no boundaries», becomes a wish. Tundra is. We are wide aware. In silence.

I have shared here some whispers of my life writing research, to reflect certain ways of listening. I described pedagogical endeavors around my representations of silence[s] in curriculum. In whispers, I turned and tuned in closer to someone's secrets; where their echoes need silence. Pause. A different listening.

As I am writing this, and reading over with attention to how I narrated this story, I remember a dream I once had, that I was a spider weaving a web of relationalities. Focusing on the tensions of these relations, I see tiny, invisible threads, which would not exist without theirs anchors. I see open-spaces. I see fragility and resilience. I strive to 
make those threads visible in my pedagogy of silenced narratives and the narratives of silence. The beauty of poetry lies in spaces created by the untold.

My whisper to you, Josephine.

\section{“Tshinashkumitin.”}




\section{References}

Abdi, A. A. (2011). De-monoculturalizing global citizenship education: The need for multicentric intentions and practices. In L. Shultz, A. A. Abdi, \& G.H. Richardson (Eds.), Global citizenship education in post-secondary institutions: Theories, practices, policies (pp. 25-39). New York, NY: Peter Lang Publishing Inc.

Andreotti, V. de O., Stein, S., Ahenakew, and Hunt, D. (2015). Mapping interpretations of decolonization in the context of higher education. Decolonization: Indigeneity, Education \& Society, 4(1), 21-40.

Archibald, J-A. (2008). Indigenous storywork: Educating the heart, mind, body, and spirit. Vanouver, BC : UBC press.

Bacon, J., (no date). Ma richesse s’appelle. Translated by Canadian Museum for Human Rights. Retrieved from https://humanrights.ca/blog/poetry-josephine-bacon

Bacon, J., (2009). Bâton de parole. Tschissinuatshitakana, Montréal, QC : Mémoires d'encrier.

Bacon, J., (2013) Un thé dans la toundra-Nipishapui nete mushuat, Montréal, QC: Mémoires d'encrier.

Battiste, M. (1986). Cognitive assimilation and Micmac literacy. Indian Education in Canada: The Legacy, 1.

Battiste, M., Kovach, M., \& Balzer, G. (2010). Celebrating the Local, Negotiating the School: Language and Literacy in Aboriginal Communities. Canadian Journal of Native Education, Aboriginal Englishes and Education Supplement, (32), 4-12.

Blood, N., Chambers, C., Donald, D., Hasebe-Ludt, E., \& Big Head, R. (2012). Aoksisowaato'op: Place and Story as Organic. In N. Ng-A-Fook \& J. Rottmann (Eds.), Reconsidering Canadian curriculum studies: Provoking historical, present, and Future. New York, NY: Palgrave Macmillan.

Buber, M. (2003). Between man and man. New York, NY: Routledge.

Chambers, C. (1999). A topography for Canadian curriculum theory. Canadian Journal of Education, 24(2), 137-150.

Chambers, C. (2006). Where do I belong? Canadian curriculum as passport home. Journal of the American Association for the Advancement of Curriculum Studies, 2. Retrieved from http://www2.uwstout.edu/content/jaaacs/vol2/chambers.htm

Chambers, C. (2012). We are all treaty people. The contemporary countenance of Canadian curriculum studies. In N. Ng-A-Fook \& J. Rottmann (Eds.), Reconsidering Canadian curriculum studies: Provoking historical, present, and future perspectives (pp. 23-38). New York, NY: Palgrave Macmillan.

Egéa-Kuehne, D. (2012). Provoking curriculum studies in multicultural societies. In N. Ng-A-Fook \& J. Rottmann (Eds.), Reconsidering Canadian curriculum studies: 
Provoking historical, present, and future perspectives (pp. 39-46). New York, NY: Palgrave Macmillan.

Emongo, L., \& White, B. (2015). L’interculturel au Québec. Montréal, QC: Presses de l’Université de Montréal.

Garson, K. (2013). Ethical considerations for internationalization: Perspectives from global citizenship education. Ottawa, ON: CBIE PhD Research studies. Retrieved from http://www.cbie-bcei.ca/wp-content/uploads/2013/03/The-Ethics-ofInternationalization-FINAL.pdf

Haig-Brown, C. (2008). Taking Indigenous thought seriously: A rant on globalization with some cautionary notes. Journal of Canadian Curriculum Studies, 6(2), 8-24.

Hall, S. (1997). Representation: Cultural representations and signifying practices. London, England : Thousand Oaks.

Hoy, H. (2001). How should I read these?: Native women writers in Canada, Toronto, ON: University of Toronto United Press.

Kanapé Fontaine, N. (2015). Petit cahier d'un voyage au loin du pays natal. Le Devoir, 22 juin. Montréal. Retrieved at : http://www.ledevoir.com/culture/livres/443360/petit-cahier-d-un-voyage-au-loindu-pays-natal

Kulnieks, A., Roronhiakewen Longboat, D., \& Young, K. (2010). Re-indigenizing curriculum: An eco-hermeneutic approach to learning. AlterNative: An International Journal of Indigenous Peoples, (6)1, 15-24.

Leclerc, R. (2014). Joséphine Bacon, Jean Chapdelaine-Gagnon, Stéphanie Filion. Lettres Québécoises: La revue de l'actualité littéraire, (154), 44-45.

Leggo, C. (2008). Narrative inquiry: Attending to the art of discourse. Language and literacy, 10(1),1-21.

McIvor, O. (2010). I am my subject: Blending indigenous research methodology and autoethnography through integrity-based, spirit-based research. Canadian Journal of Native Education, 33(1), 137-151.

Mishra Tarc, A. (2011). Reparative curriculum. Curriculum Inquiry, 41(3), 350-372.

Ng-A-Fook, N. (2010). An/other bell ringing in the sky: Greenwashing, curriculum, and ecojustice. Journal of the Canadian Association for Curriculum Studies, 8(1), 4167.

Pidgeon, M. E. (2008). It takes more than good intentions: Institutional accountability and responsibility to Indigenous higher education. (Doctoral Dissertation, Simon Fraser University). Retrieved from https://open.library.ubc.ca/cIRcle/collections/ubctheses/24/items/1.0066636 
Pinar, W. (1974). Currere: Toward reconceptualization. In J. Jelinek (Ed.), Basic problems in modern education (pp. 147-171). Tempe, AZ: Arizona State University, College of Education.

Pinar, W. F. (2006a). Race, religion and a curriculum of reparation. New York, NY: Palgrave Macmillan.

Pinar, W. F. (2006b). Exile and estrangement in the internationalization of curriculum studies. Journal of the American Association for the Advancement of Curriculum Studies, (2)6. Retrieved from http://www2.uwstout.edu/content/jaaacs/vol2/pinar_exile.htm

Pretceille, M. (2013). L'education interculturelle (pp. 94-117). Presses Universitaires de France. ISBN : 9782130619734.

Ralston Saul, J. (2015). Le grand retour. (D. Poliquin, trans.) Montreal, PQ: Les Éditions du Boréal.

Simon, R. (2012). Towards a hopeful practice of worrying: The problematics of listening and the educative responsibilities of Canada's Truth and Reconciliation Commission. In P. Wakeman \& J. Henderson (Eds.), Reconciling Canada: Critical perspectives on the culture of redress. Toronto, ON: University of Toronto Press.

Simon, R. I. (2005). The touch of the past: Remembrance, learning, ethics. New York, NY: Palgrave.

Stanley, T. (1999). A letter to my children: Historical memory and the silences of childhood, (pp.34-33). In J. Robertson (Ed.), Teaching for a tolerant world, Grades K-6: Essays and resources. Urbana, Ill.: National Council of Teachers of English.

Tuck, E., \& Gaztambide-Fernández, R. (2013). Curriculum, replacement, and settler futurity. Journal of Curriculum Theorizing, 29(1), 72-89.

Tuck, E., \& Yang, K. W. (2012). Decolonization is not a metaphor. Decolonization: Indigeneity, Education \& Society, 1(1), 1-40. Retreved from http://decolonization.org/index.php/des/article/view/18630/15554

Uryu, M., Steffensen, S. V., \& Kramsch, C. (2014). The ecology of intercultural interaction: Timescales, temporal ranges and identity dynamics. Language Sciences, 41, (Part A), 41-59.

Wang, H. (2004). The call from the stranger on a journey home: Curriculum in a third space. New York, NY: Peter Lang.

Weenie, A. (2008). Curricular theorizing from the periphery. Curriculum Inquiry, 38(5), 545-557.

Werner, W. (2000). Reading authorship into texts. Theory \& Research in Social Education, 28(2), 193-219. 


\section{Endnote}

${ }^{1}$ «Après avoir séquestré, déculturé, affamé, infecté, violé et disséminé son peuple, on présente Joséphine Bacon comme « une figure incontournable de la culture autochtone ». Que pense-t-elle de sa popularité? Dira-t-elle qu'on joue à l'Indien, comme l'a écrit Jim Harrison dans La route du retour, ou qu'on se fait des accroires sur nous-mêmes, sur ce Nous qui, il n’y a pas vingt-cinq ans, lançait des roches aux Mohawks durant la crise d’Oka ?» (Leclerc, 2014, p. 24). 